\title{
HUBUNGAN ANTARA TINGKAT AKTUALISASI DIRI DENGAN KEBERMAKNAAN HIDUP PADA PRIA HOMOSEKSUAL
}

\author{
Nia H. Septiani \\ Fakultas Psikologi UIN Sunan Gunung Djati Bandung, Jl. A.H Nasution No. 105 Bandung \\ email: cychant_ique@yahoo.com
}

\begin{abstract}
Abstrak
Penelitian ini secara khusus menyelidiki hubungan antara aktualisasi diri dengan kebermaknaan hidup pada pria homoseksual di himpunan x Kota Bandung. Ketertarikan peneliti berawal dari kondisi masyarakat yang belum bisa menerima kahadiran kaum pria homoseksual sepenuhnya, banyak tekanan-tekanan yang dialami kaum pria homoseksual yang dapat menghambat pengaktualisasian dirinya yang diduga akan berkaitan pula dengan kebermaknaan hidupnya. Rancangan yang akan digunakan dalam penelitian ini adalah rancangan non eksperimental dengan metode korelasional. Data penelitian diperoleh dari alat ukur yang menjaring data aktualisasi diri berdasarkan konsep teori yang dikemukakan oleh Maslow (1984). Sedangkan alat ukur yang digunakan untuk memperoleh data kebermaknaan hidup disusun oleh James Crumbaugh dan Leonard Maholick (Frankl, 1984) yang diberi nama The Purpose in Life Test. Hasil analisis data menunjukkan bahwa koefisien korelasi kedua variabel adalah sebesar 0.685 dengan $P_{v}$ sebesar 0,000 pada taraf signifikansi $\alpha=0,05$ dengan arah pengujian dua sisi. Berdasarkan hasil uji signifikansi, diperoleh $t_{\text {hitung }}$ sebesar 4,98. Dengan taraf signifikansi $\alpha=0,05$ serta derajat kebebasan $\left(\mathrm{dk}_{\mathrm{n}-2}\right)=28$ untuk pengujian dua sisi diperoleh harga $\mathrm{t}_{\text {tabel }}$ sebesar 2.048 . Hal tersebut menunjukkan bahwa terdapat hubungan positif yang signifikan antara aktualisasi diri dengan kebermaknaan hidup.
\end{abstract}

Kata kunci: homoseksual, aktualisasi diri, dan kebermaknaan hidup

\section{Abstract}

This research specifically observes the correlation between self actualization level and life meaning of homosexual men in a Bandung association. This research has been done because condition of society who has not been able to accept the existing of homosexual men in the association, many probles must be faced by them which enables to disturb their actualization with assumption that it relates to their life meaning. The design used in this research is non experimental design and correlation method. The research data are taken from the measurement tool encompassing self actualization data based on theory concept said by Maslow (1984). Whereas, the measurement tool used to get the date of the life meaning composed by James Crumbaugh dan Leonard Maholick (Frankl, 1984) named The Purpose in Life Test. The result of analysis shows that correlative coefficient of both variables is 0.685 with $P_{v}=0,000$ on significant standard $\alpha=0,05$ by two side tests. Basing on the result of significant test, it is known that $t_{\text {hitung }}=4,98$. The result of data analysis shows that correlative coefficient of both variables is 0.685 with $P_{v}$ $=0,000$ on significant standard $\alpha=0,05$ by two side tests.basing on the result of significant test, it is known that $t_{\text {hitung }}=4,98$. With standard significance $\alpha=0,05$ and ( $d k_{n}$. $\left.{ }_{2}\right)=28$ for two side test, it is know that $t_{\text {tabel }}=2.048$. These results show that there is significant positive correlation between self actualization and life meaning.

Keywords: homosexual, self actualization, and meaningfulness of life 


\section{PENDAHULUAN}

Sejak dini manusia telah diajarkan tentang adanya Adam dan Hawa. Hal ini bukan saja hanya berarti bahwa manusia terdiri dari dua jenis kelamin, tetapi juga mengandung pengertian adanya pola tingkah laku tertentu yang berbeda untuk setiap anggota dari setiap jenis kelamin. Secara umum laki-laki memang mempunyai kecenderungan untuk lebih menyukai wanita dan wanita lebih menyukai lakilaki sebagai pasangan seksnya. Golongan yang umum ini adalah golongan yang berorientasi heteroseksual. Akan tetapi, ternyata dalam masyarakat mana pun terdapat sebagian kecil yang berorientasi homoseksual. Mereka adalah laki-laki yang bertingkah laku tidak sesuai dengan jenis kelaminnya. Secara badaniah mereka adalah laki-laki tetapi dirinya merasa lebih tertarik pada jenis laki-laki lagi.Tentu saja hal tersebut memiliki berbagai macam alasan dan faktor-faktor tertentu yang melatarbelakanginya. Salah satu faktor yang melatarbelakanginya adalah faktor lingkungan dan pendidikan orang tua pada masa kanak-kanak (Amiruddin \& Sulistyo, 2004).

Menurut Martin dan Lyion dalam Robert Crooks (1983) pengertian dari homoseksual yaitu: "A homosexual person is an individual whose primary erotic, psychological, emotionnal, and social interest is an individual the same sex, even though that interese may not overtly expressed (Seorang homoseksual adalah individu yang memiliki minat atau ketertarikan secara birahi, psikologis, emosi, dan juga sosial terhadap sesama jenis kelamin, dimana hal tersebut merupakan minat (ketertarikan) yang tidak lazim untuk di tunjukkan)".

Pada saat ini keberadaan kaum homoseksual bukanlah suatu hal yang asing lagi, makin nyata dan jelas bahwa di sekitar kita terdapat adanya suatu gejala yang dikenal masyarakat sebagai komunitas homoseksual. Makin hari makin banyak perilaku homoseksual yang tampak secara terbuka dalam masyarakat. Ada organisasi-organisasi homoseksual, majalah homoseksual, cafe-cafe dan tempat hiburan khusus untuk homoseksual, bahkan di luar negeri yang sudah melegalkan komunitas homoseksual, terdapat siaran televisi khusus untuk komunitas ini.

Pada masa lampau homoseksual dianggap sebagai perilaku seks yang menyimpang, sedangkan kini terutama di dunia barat sudah diterima sebagai hal yang lumrah dan dianggap sebagai sifat yang terbawa sejak lahir. Penganut homoseksual di Indonesia saat ini tidak dapat dipungkiri lagi, meskipun kaum homoseksual yang hidup di Indonesia belum sebebas negara barat karena mayoritas menganut norma timur dan agamis. Sementara di beberapa negara di barat homoseksual sudah bisa diterima sebagai pilihan hidup. Contohnya di Provinsi Basque, Spanyol, yang mengizinkan warganya untuk menikah dengan sesama jenisnya. Undang-undang baru di Basque itu memberikan persamaan hak bagi pasangan hidup bersama tanpa nikah untuk mengadopsi anak, pengenaan pajak serta perawatan kesehatan, membuat mereka setara dengan pasangan yang menikah secara resmi (Bisnis Indonesia. 2003).

Adanya pengaruh dari Barat mengenai kebebasan homoseksual sebagai pilihan hidup mempengaruhi keterbukaan kaum homoseksual di Indonesia. Terbukanya kaum homoseksual dapat dilihat dari adanya perkumpulanperkumpulan ataupun organisasi - organisasi khusus bagi kaum homoseksual. Hal ini sesuai dengan apa yang diungkapkan oleh Fryda (2001) bahwa dalam kondisi kehidupan yang tidak bermakna, kaum gay mencoba untuk mengubahkondisi untuk menemukan kebahagiaan dengan bertemu teman-teman yang mempunyai pengalaman sama, serta berkumpul dan melakukan berbagai aktifitas bersamasama. Selain itu, mereka ingin membuat sanggar, dan terus berusaha agar keluarga dan masyarakat menerima mereka.

Di Jerman pasangan gay diakui legal oleh legislatif Jerman, dan memberi mereka hak yang sama, seperti pasangan gay yang akan menikah di pemerintah lokal, dan berhak meminta pengadilan untuk memberikan keputusan penceraian apabila memang dikehendaki. Pasangan ini juga memberikan hak yang sama seperti pasangan heteroseksual menyangkut harta warisan dan asumsi kesehatan. (Adian Husiana, 2002. Homoseksual dan Umat Islam).

Hukum tentang homoseksual atau lesbianisme di Indonesia telah diatur dalam kitab Undang-Undang Hukum Pidana (KUHP) pasal 292, yang isinya sebagai berikut: "Orang yang cukup umur, yang melakukan perbuatan cabul dengan orang lain sesama kelamin, yang diketahuinya atau sepatutnya harus diduga, bahwa belum cukup umur, di ancam dengan pidana penjara paling lama lima tahun". Dengan demikian, di Indonesia homoseksual atau les- 
bianisme merupakan perbuatan yang bertentangan dengan hukum agama maupun hukum negara yang diterapkan.

Berdasarkan pada hukum agama dan hukum negara umumnya masyarakat Indonesia memandang homoseksual sebagai perilaku yang menyimpang dan praktek kejahatan kriminal yang tidak patut dipromosikan apalagi dilegalkan. Penilaian masyarakat Indonesia yang secara umum memandang negatif terhadap perilaku homoseksual tersebut tentunya membentuk sikap yang negatif pula, karena menurut Hovlad dalam Elizabeth Hurlock (1999), pada dasarnya manusia adalah makhluk yang pasif, mereka mempelajari stimulus tersebut dan akhirnya membentuk sikap.

Mereka yang merupakan komunitas homoseksual juga hanyalah manusia biasa yang menginginkan persamaan hak dan ingin diperlakukan sama dengan yang lainnya hanya saja ada permasalahan pada orientasi seksualnya. Akan tetapi, tidak dapat dipungkiri bahwa masyarakat umum sendiri belum dapat menerima orientasi homoseksual. Masyarakat masih menganggapnya sebagai penyakit, kelainan atau dosa (dalam masyarakat yang masih sangat berpegang pada agama seperti Indonesia) (Wirawan,1990). Jadi timbul pertentangan antara kaum homoseksual sebagai minoritas yang terus ingin diperlakukan dan diberi hak yang sama dengan mayoritas kaum heteroseksual yang tidak dapat menerima eksistensi dari komunitas homoseksual. Lain halnya dengan beberapa negara di luar negeri yang telah melegalkan komunitas ini. Bahkan sudah ada undang-undang yang membolehkan perkawinan antara sejenis kelamin. karena di luar negeri homoseksualitas tidak dapat dinilai melanggar etika atau moral.

Berdasarkan kamus psikologi, homoseksual merupakan kecenderungan memiliki hasrat seksual atau mengadakan hubungan dengan anggota dari jenis kelamin yang sama (Kartono, 2000). Sedangkan menurut dr. Teddy Hidayat, Sp.,K.J., psikiater di Rumah Sakit Hasan Sadikin Bandung (Pikiran Rakyat online, 2005), yang dimaksud dengan homoseksual adalah rasa tertarik secara perasaan (rasa kasih sayang, hubungan emosional) dan atau secara erotik, baik secara lebih menonjol (predominan) atau semata-mata (eksklusif), terhadap orangorang yang berjenis kelamin sama, dengan atau tanpa hubungan fisik (jasmaniah). Kehidupan para homoseks ada yang sukses dan ada pula yang tidak, profesi mereka beraneka ragam, ada yang berprofesi sebagai dokter, eksekutif muda, pengusaha, model, kapster salon, dan sebagainya. Mereka ada di sekitar kita, tetapi belum tentu kita mengenalinya (Teddy, 2005). Laki-laki homoseks sering disebut dengan gay, sedangkan perempuan homoseks disebut lesbian (Oetomo, 2001). Meskipun sejak 1983 homoseksualitas tidak lagi digolongkan sebagai gangguan atau penyakit jiwa maupun sebagai deviasi (penyimpangan) seksual atau "parafilia", tetapi sebagian masyarakat masih menolak homoseksualitas (Oetomo, 2001).

Perilaku homoseksual, mungkin saja berada di tengah-tengah keluarga kita. Berdasarkan catatan LSM Abiasa dan Komisi Penanggulangan AIDS Jawa Barat yang terlibat pendampingan untuk HIV/ AIDS, di Kota Bandung saja, tak kurang dari 656 orang tercatat sebagai pria homoseksual, dan di Jawa Barat diperkirakan tak kurang dari 6.000 orang. Jumlah tersebut cenderung terus bertambah. Pasalnya, berdasarkan penuturan beberapa orang yang terlibat dalam komunitas yang mereka bentuk, ternyata ada yang baru tahu bahwa ada komunitas gay sehingga baru bergabung. Padahal mulanya perilaku itu dipendamnya, karena ia berada di lingkungan keluarga yang tampak harmonis.

Kaum homoseksual saat ini sudah mulai terbuka, tapi mereka tetap merupakan kelompok yang eksklusif jika berada dalam masyarakat luas, karena itulah mereka mengidentifikasikan dirinya melalui sinyal-sinyal, simbolsimbol, serta bahasa tersendiri ketika mereka berinteraksi dengan kalangannya sendiri, hal tersebut penulis temui di lapangan ketika melakukan studi pendahuluan, kebanyakan dari pria homoseksual pada awalnya merasa bahwa hidup yang dijalaninya tidaklah bermakna, mereka seringkali diliputi perasaan hampa, malu dan tidak bermakna. Dalam kondisi yang tidak bermakna ini, pria gay mencoba untuk merubah kondisi untuk menemukan kebahagiaan dengan bertemu teman-teman yang berorientasi homoseksual dan mempunyai pengalaman sama, serta berkumpul dan melakukan berbagai kegiatan bersama-sama, selain itu juga pria gay tertarik untuk membuat suatu himpunan yang dapat mewadahi komunitasnya, menurut pengamatan penulis, pria gay terus berusaha agar keluarga dan masyarakat dapat menerima mereka. Usaha-usaha tersebut dilakukan sebagai salah satu bentuk dari aktualisasi dari pria 
gay agar keberadaan mereka dapat diterima seutuhnya oleh keluarga dan lingkungan, namun pada kenyataannya, ditemukan adanya para pria gay yang belum mampu mengaktualisasikan dirinya dengan maksimal sehingga cukup menghambat dalam menemukan makna hidup.

Meskipun pria gay terus berusaha agar keberadaannya dapat diterima namun tidak sedikit pula usaha masyarakat untuk menolak keberadaan pria gay di tengah-tengah lingkungan masyarakat. Berdasarkan hasil wawancara dengan beberapa pria gay pada studi pendahuluan, penolakan masyarakat kepada pria gay tidak hanya pada perilaku homoseksualitas saja, tetapi juga mengarah pada individu. Sikap tersebut muncul dalam kehidupan sehari-hari mulai dari keluarga dan teman dekat sampai masyarakat luas dalam bentuk mencemooh, membatasi pergaulan dengan mereka dan memperlakukan mereka secara diskriminatif sampai perilaku menyerang. Adanya stigma di masyarakat menyebabkan mereka tersudut dan menjadi objek serta sasaran cemoohan atau celaan, inipun terjadi di lingkungan keluarga. Seperti orang tua yang sulit untuk menerima kehadiran anak yang gay. Maka tak salah bila kemudian para homoseksual mengalami problem psikologis. Seorang pria dewasa muda homoseksual yang tidak dapat berdamai dengan dirinya sendiri, akan menyebabkan munculnya gejala-gejala gangguan kejiwaan. Gejala gangguan tersebut dapat berupa depresi, cemas, panik, fobia, ketidakbermaknaan hidup, bahkan dapat terjadi sampai gangguan psikotik, hal tersebut sama seperti yang diungkapkan oleh Teddy, (2005).

Salah satu bukti sikap masyarakat menolak komunitas homoseksual antara lain munculnya tantangan dan ancaman untuk membakar Hotel Dana di Solo yang direncanakan sebagai tempat Rakernas Jaringan Lesbian dan Gay Indonesia (JLGI) I pada tanggal 10-11 September 1999. Ancaman tersebut berasal dari masyarakat yang mengatasnamakan kelompok masyarakat tertentu. Dan yang terbaru adalah adanya penolakan keras dari masyarakat luas, seperti adanya penolakan dari BEM Mahasiswa se-Jawa Timur, Fraksi-fraksi partai tertentu, MUI Jawa Timur, Front Pembela Islam, hingga para aktivis dari beberapa organisasi Islam yang menolak keras ketika akan diadakannya konferensi internasional lesbian dan gay atau konferensi ILGA (International lesbian \& gay Association) se-Asia yang ke empat, pada tanggal 28 Maret 2010 yang bertempat di Surabaya (liputan 6.com, 2010). Penyerangan dengan kekerasan juga dialami kaum gay pada acara pesta kesenian kaum gay yang dikenal dengan acara "Kerlap-kerlip Warna Kedaton (KKWK) 2000 pada tanggal 8 November 2000 di Kaliurang Yogyakarta. Acara yang dihadiri sekitar 200 gay dari berbagai daerah tersebut berakhir dengan tragis. Sekelompok massa yang berjumlah kurang lebih 100 orang dengan membawa berbagai senjata tajam datang memporak-porandakan acara (Gaya Nusantara, 2003).

Menurut Psikolog Erida Rusli Sukardi (Hai, 2001), sikap tidak menerima yang diperlihatkan lingkungan sekitar menyebabkan seorang homoseksual merasa tertekan dan terkucil. Mereka sering diliputi perasaan bersalah dan harus hidup dalam kepura-puraan. Misalnya ketika memiliki istri dan menikah, tujuannya hanyalah untuk mengejar status normal dan diterima masyarakat. Selain itu tidak sedikit pasangan yang sudah menikah normal (heteroseksual), memiliki relasi dengan sesama jenis dan akhirnya mendorong ia melakukan hubungan biseksual. Artinya, hubungan dengan istri berjalan terus, dengan pasangan sejenispun ia lanjutkan. Oetomo (2001) pendiri organisasi gay pertama di Indonesia, berdasarkan pengalaman dan pengamatannya menambahkan bahwa sebagian besar homoseksual di Indonesia masih diliputi rasa tidak pasti, malu, takut dan banyak yang harus hidup dalam kesejahteraan jiwa dibawah optimal.

Tekanan jiwa yang dialami kaum homoseksual tidak hanya disebabkan penolakan masyarakat. Kaum homoseksual sendiri juga mengalami konflik batin antara bertahan menjadi homoseksual dengan akibat dijauhi keluarga dan masyarakat, menjadi homoseksual tanpa menunjukkan identitas dirinya, atau berusaha menjadi heteroseksual. Konflik batin dan penolakan masyarakat tersebut menyebabkan kaum homoseksual sering merasa hampa dan kehilangan kebermaknaan hidup (Fryda, 2001).

Setiap manusia pada dasarnya memiliki hasrat mendasar yaitu hasrat untuk hidup bermakna (Bastaman, 1996). Kegagalan untuk mencapai hidup bermakna dapat mengakibatkan berbagai persoalan mulai dari sindrom ketidakbermaknaan hidup sampai dengan timbulnya neurosis. Sindrom tersebut menimbulkan frustrasi eksistensial, yaitu individu mengalami ketidakpastian mengenai apa yang harus diper- 
buat, dan apa yang seharusnya diperbuat. Frustrasi ini menyebabkan individu kehilangan minat, kurang inisiatif serta hampa. Neurosis yang timbul dapat berupa depresi, alkoholism, obsesionalisme, serta tindak kejahatan.

Maslow (Goble, 1987) menjelaskan bahwa kebermaknaan hidup dapat dicapai apabila individu memiliki sistem nilai, tetapi sistem nilai bukan satu-satunya jalan untuk mencapai hidup bermakna. Frankl (dalam Koeswara, 1987) mengemukakan pendapatnya bahwa manusia dapat menemukan makna hidup melalui realisasi nilai-nilai manusiawi yang mencakup nilai kreatif, nilai estetis, nilai etis dan nilai pengalaman. Kebermaknaan hidup berhubungan dengan tingkat pendidikan, kecerdasan dan kondisi sosial ekonomi individu. Hal ini berarti, bahwa manusia dapat menemukan makna hidup melalui kerja, penemuan keindahan dan kebenaran serta berbagai pengalaman.

Semua manusia mempunyai kecenderungan yang dibawa sejak lahir untuk mengaktualisasikan dirinya. Tidak ada segi pertumbuhan dan perkembangan manusia yang dapat beroperasi terlepas dari kecenderungan aktualisasi diri (Rogers, 1961). Menurut Maslow kecenderungan mengaktualisasikan diri dapat dipahami sebagai hasrat individu untuk menjadi seseorang yang sesuai dengan keinginan dan potensi yang dimilikinya. Suatu hasrat untuk menyempurnakan "diri" melalui pengungkapan segenap potensi yang dimilikinya (Koeswara, 1987). Maslow juga berpendapat bahwa aktualisasi diri tidak hanya berupa penciptaan kreasi atau karya berdasarkan bakat dan kemampuan khusus, tetapi dapat dicapai dengan jalan membuat yang terbaik, bekerja dengan sebaik-baiknya sesuai dengan bidangnya.

Seperti telah disinggung sebelumnya, bahwa dalam masyarakat yang belum bisa menerima kahadiran kaum gay sepenuhnya, banyak tekanan-tekanan yang dialami kaum gay yang dapat menghambat pengaktualisasian dirinya yang diduga akan berkaitan pula dengan kebermaknaan hidupnya. Oleh karena itu, berdasarkan latarbelakang yang telah diuraikan sebelumnya, maka penulis ingin mengkaji lebih jauh apakah ada hubungan antara tingkat aktualisasi diri dengan kebermaknaan hidup pada pria homoseksual, atau yang biasa dikenal dengan istilah gay.

Pria homoseksual sebagai subjek yang akan disoroti dalam penelitian ini, adalah individu yang memiliki orientasi seks yang me- nyimpang. Mereka adalah laki-laki yang bertingkah laku tidak sesuai dengan peran jenis kelaminnya. Secara badaniah mereka adalah laki-laki tetapi dirinya merasa lebih tertarik pada jenis laki-laki lagi.

Orientasi seks yang menyimpang ini dapat menimbulkan berbagai permasalahan dalam pengaktualisasian dirinya seiring dengan munculnya permasalahan dalam kehidupannya, mulai dari penolakan keluarga, teman sebaya hingga penolakan masyarakat yang memicu adanya konflik batin dalam diri homoseksual. Hal ini menyebabkan homoseksual sering merasa hampa dan kehilangan kebermaknaan hidup. Oleh karena itu, seperti telah dipaparkan sebelumnya diduga sejauhmana kaum homoseksual dapat mengaktualisasikan dirinya dalam kehidupan akan berkaitan dengan tingkat kebermaknaan hidupnya. Untuk menguji dugaan tersebut maka peneliti tertarik untuk menelaah lebih jauh mengenai aktualisasi diri dan kebermaknaan hidup yang dialami para homoseksual serta ada-tidaknya hubungan diantara keduanya. Untuk keperluan tersebut, penelitian akan dilakukan pada sebuah himpunan homoseksual di kota Bandung. Namun, karena berbagai pertimbangan peneliti tidak akan menyebutkan nama himpunannya sehingga selanjutnya himpunan tersebut hanya akan disebut sebagai "Himpunan X"

\section{Homoseksual}

Istilah homoseksual dikemukakan sebagai antitetis dari istilah heteroseksual. Istilah ini digunakan untuk menggambarkan orang yang pilihan orientasi seks dasarnya, diwujudkan atau tidak, dilakukan ataupun tidak, diarahkan kepada sesama jenis kelaminnya. Menurut Kartono (2000) homoseksualitas adalah kecenderungan memiliki hasrat-hasrat seksual atau mengandalkan hubungan dengan anggota jenis kelamin yang sama.

Menurut Scoot (dalam Eysenck, 1977) merumuskan definisi tentang homoseksual dianggap sangat sulit untuk dicapai, hal ini dikarenakan adanya kebingungan antara deskripsi perilaku homoseksual dengan penjelasan mengenai homoseks (penjelasan yang abstrak mengenai pencarian atau penelitian diri akan kejelasan perilaku yang mereka miliki). Umumnya pada saat itu definisi tentang homoseksual hanya ditinjau dari segi apa yang terlihat, pandangan atau perilaku secara umum, dan perilaku. 
Secara umum perilaku seksual tidak hanya dilihat dari seberapa besar munculnya hasrat sebagai respon yang jelas (nyata) pada saat praktek, karena bagi individu tertentu mereka mengekspresikan perilakunya melalui fantasi. Oleh karena itu, definisi, penilaian, dan juga dalam mengklasifikasikan tidak hanya melihat dari apa yang mereka lakukan, tapi juga dari segi apa yang mereka sukai dan jalan yang mereka pilih dalam menentukan pasangan seksual mereka.

Definisi homoseksual menurut Greek (dalam Allyn \& Bacon, 1993) menjelaskan bahwa seorang homoseksual yaitu seseorang yang memiliki daya tarik erotis dan lebih memilih untuk membangun hubungan asmaranya dengan sesama jenis. Sementara Supratiknya (2000) berpendapat bahwa homoseksual adalah perilaku seksual yang ditujukan pada pasangan sejenis. Bila terjadi diantara kaum wanita disebut lesbian, sedangkan homoseksual pada kaum pria biasa disebut dengan gay (Bell dalam Koeswara, 1992).

Sedangkan definisi yang dijelaskan oleh Martin dan Lyion (dalam Robert Crooks, 1983) lebih lengkap lagi karena meliputi dua hal penting yang mengandung konteks tentang aktifitas seksual, perasaan, dan juga persepsi akan diri individu itu sendiri, sehingga dari konteks tersebut kita dapat mengetahui akan perilaku seksualnya, emosi, dan juga pemahaman akan dirinya sendiri. Berdasarkan pemahaman di atas maka Martin dan Lyion (dalam Allyn \& Bacon, 1993) mendefinisikan bahwa seorang homoseks adalah individu yang memiliki minat (ketertarikan) secara birahi, psikologis, emosi, dan juga sosial terhadap sesama jenis kelamin, dimana hal tersebut merupakan minat (ketertarikan) yang tidak lazim untuk ditunjukkan.

Istilah homoseksual yang menunjukkan adanya minat ke sesama jenis kelamin bisa dialami oleh pria ataupun wanita. Homoseksual pria biasa disebut dengan istilah gay sedangkan homoseksual wanita disebut dengan lesbian (Allyn \& Bacon, 1993).

Stoller mengemukakan bahwa homoseksual merupakan dorongan seksual yang ditujukan pada sesama jenis kelamin (Sue dalam Lumenta, 1996). Kebanyakan orang homoseksual lebih dapat menikmati hubungan seksual dan mencintai sesama jenisnya daripada dengan lawan jenisnya (Duke dan Norwicki dalam Goble, 1987). Memang pada saat ini para ahli masih berbeda pendapat. Ada yang berpendapat bahwa homoseksual merupakan suatu kelainan atau penyakit, namun ada beberapa ahli yang berpendapat bahwa homoseksual hanya merupakan penyimpangan perilaku seksual. Bahkan ada yang berpendapat bahwa homoseksual adalah variasi yang normal sebagai ekspresi seksual.

Banyak teori yang berusaha mengungkap fenomena homoseksualitas, mengapa seseorang menjadi homoseksual, baik teori yang mengkaji kromosom pada tubuh manusia maupun hal lainnya. Stevenson (1985) menyatakan bahwa pada beberapa kasus penelitiannya ditemukan adanya kromosom spesifik $\mathrm{X}$ yang dijumpai pada orang-orang homoseksual.

Teori lain berusaha mengungkap orientasi seksual manusia sebagai suatu kontinum yang bisa bergeser, semacam gradasi dari heteroseksual ke homoseksual dan sebaliknya. Kinsey, dkk. (1949) mengatakan bahwa homoseksualitas pada dasarnya merupakan suatu bagian dari kontinum seksual manusia. Kinsey menunjukkan bahwa dalam suatu masyarakat heteroseksual, homoseksual terdapat dalam berbagai variasi penampakan. Hal itu berarti banyak orang mempunyai kecenderungan sifat homoseksual dalam berbagai tingkatan. Pengamatannya menitikberatkan pada perilaku seksual seseorang yang ada, bukan pada kondisi maupun dorongan seksualnya.

Homoseksual merupakan suatu dorongan yang didasari tidak hanya oleh ketertarikan secara fisik tidak dapat dipungkiri bahwa ketertarikan fisik mempengaruhi dorongan homoseksual pria dalam memilih pasangan tidak semata-mata karena dorongan seksual saja, tetapi juga untuk memenuhi kebutuhan memberi dan menerima kasih sayang, perhatian, rasa cinta, dan rasa memiliki.

Dari segi fisiologis, para ahli saraf menemukan bahwa konstelasi otak para homoseksual ternyata berbeda dengan otak orang yang normal. Ukuran hipotalamus pada pria homoseksual (gay) sepertiga ukuran hipotalamus dari otak pria normal. Ukuran hipotalamus tersebut serupa dengan ukuran hipotalamus pada wanita. Hipotalamus sendiri adalah organ otak yang berisi ribuan sel saraf yang diantaranya berfungsi mengatur perilaku seseorang. Hal tersebut menyebabkan kesimpangsiuran pelepasan hormon dalam tubuh seorang homoseksual. Hal ini menyebabkan orang tersebut justru baru "bergetar" kalau melihat orang sejenis, bukan lawan jenisnya. 
Berdasarkan sebuah artikel yang ditulis Hatta dalam Jawa Pos (19 Juli 1999) seorang homoseks tidak selalu tertarik secara seksual ke setiap sesama jenisnya, sama halnya dengan seorang heteroseksual yang tidak tertarik ke setiap lawan jenisnya. Ketertarikan seksual berjalan seiring dengan keinginan untuk suatu hubungan dan cinta. Seorang homoseksual seOlalu merindukan cinta dan hubungan dari orang yang dicintai dan hubungan dari orang yang ia minati. Selain dari fakta bahwa mereka tertarik dengan orang yang memang sejenis, kualitas hubungan mereka tidak berbeda dengan hubungan kaum yang berbeda jenis (heteroseksual), contohnya komitmen emosional, saling ketergantungan, dan keinginan untuk bersama selamanya.

Namun, tidak selalu pria yang memilki ketertarikan ke sesama jenis dikatakan seorang homoseksual karena ada kemungkinan bahwa dia termasuk ke dalam golongan biseksual, transgender, atau bahkan pelacur pria. Adapun perbedaan dari keempat kemungkinan itu adalah dari segi kejiwaannya sebagai berikut: $P a$ da homoseksual, tubuh pria, jiwa pria, tertarik pada pria. Pada biseksual, tubuh pria, jiwa pria, tertarik pada pria dan wanita. Pada transgender, tubuh pria, jiwa wanita, tertarik pada pria. Pada pelacur pria, tubuh pria, jiwa pria, mau berhubungan seks dengan pria karena kebutuhan ekonomi/karena uang.

Jika ditinjau dari segi penggolongan maka homoseksual dalam DSM III (suatu pedoman klarifikasi gangguan mental) sudah tidak dimasukkan lagi sebagai salah satu penyakit gangguan mental, kecuali jika orang tersebut merasa bersalah/tertekan dengan keadaannya itu. Jika orang tersebut diberi psikoterapi maka yang diatasi adalah rasa bersalah atau tertekannya. Jadi dia akan diberitahu bahwa ketertarikannya secara seksual dengan sesama jenis bukanlah suatu penyakit. Bila rasa bersalah depresinya bisa diatasi maka orang ini akan dapat menerima keadaannya sebagai homoseks. (Anonim, 2005).

Sebelumnya pengklasifikasian tentang homoseksual amat terbatas, hal ini dikarenakan tidak jelasnya perilaku tentang heteroseksual maupun homoseksual. Usaha untuk mengklasifikasikannya harus menggabungkan ciri yang tidak terlihat dengan ciri yang terlihat mengenai homoseksual, hal inilah yang menjadi alasan sulitnya dalam pencapaian definisi (Eysenck, 1977).
Menurut Wess (dalam Eysenck, 1977) dengan membedakan individu yang pasif dan yang aktif dalam hubungan seksualnya, yang merupakan salah satu usaha, namun sejauh ini hanya sedikit memberikan pemahaman mengenai pengklasifikasian homoseksual. Hal ini selaras dengan apa yang di ungkapkan oleh Sawitri Supardi (2005) yaitu walaupun tipe aktif adalah tipe maskulin dimana pada relasi homoseksual tipe ini menunjukkan sikap aktif, sedangkan tipe pasif sering lebih mengambil alih setiap pemunculan sikap yang feminim (psikofeminim), sehingga kemudian tipe ini justru menjadi tipe yang betul-betul menderita, namun pada umumnya sering partner menginginkan aktivitas untuk saling mengisi di dalam relasi homoseksualnya (reciprocal).

\section{Kebermaknaan hidup}

Frankl adalah tokoh pertama yang menggunakan istilah logoterapi sekitar tahun 1920-an. Berbeda dengan tokoh psikologi eksistensial lain di Eropa yang pesimistik dan anti agama, Frankl memiliki pandangan yang optimistik terhadap keberadaan manusia dan menempatkan agama sebagai salah satu sistem nilai yang berpengaruh besar terhadap kehidupan manusia (Siahaan dalam Bastaman, 1996).

Psikologi eksistensial membahas segala kemampuan manusia yang tidak mendapatkan pembahasan secara sistematis dalam aliran positivis-behaviourisme ataupun dalam teori klasik psikoanalisa. Misalnya masalah values, proses menjadi (becoming), kreativitas, afeksi, tanggung jawab, dan kebermaknaan (Koeswara, 1987). Salah satu prinsip dasar dari aliran ini adalah keberadaan mengatasi dunia (being-beyond-the-world). Maksudnya adalah manusia memiliki kemungkinan yang luas untuk mentransendir atau melampaui atau mengatasi "diri“ dan lingkungannya, serta merealisasikan potensinya. Konsep mengatasi pada psikologi eksistensial ini dapat menerangkan dan mendeskripsikan secara menarik tentang kemampuan manusia mentransendir "diri" dan lingkungannya, walaupun lingkungan yang dihadapinya tersebut sangat menindas, hororistik, dan penuh penderitaan (Djatmiko dalam Hassan, 1976).

Frankl menghindari kerancuan dengan pendekatan eksistensial lainnya, dengan menyebut pendekatannya, baik dalam kontek teoretik maupun terapeutik, dengan sebutan logo- 
terapi (Yalom, 1980). Frankl menggunakan istilah "analisis eksistensial" sebagai sinonim dari logoterapi. Logoterapi berasal dari dua kata, yaitu logos dan therapy. Logos berarti makna dan therapy berarti prosedur untuk menyembuhkan atau meringankan suatu penyakit. Logoterapi itu sendiri berbicara mengenai arti eksistensi manusia dan kebutuhan manusia akan makna, dan juga teknik-teknik terapeutik khusus untuk menemukan makna dalam kehidupan (Schultz, 1991). Kebermaknaan hidup sebagai salah satu dari tiga prinsip utama logoterapi akan dapat lebih dipahami dalam konteks pemahaman logoterapi secara keseluruhan. Tiga konsep utama yang menjadi dasar filosofis logoterapi adalah kebebasan berkeinginan (freedom of will), keinginan akan makna (will of meaning), dan makna hidup (meaning of life) (Koeswara, 1992).

Kebebasan berkeinginan (freedom of will). Frankl sangat menentang pendirian dalam psikologi dan psikoterapi yang memandang kondisi manusia ditentukan oleh instinginsting biologis, konflik-konflik masa kanakkanak, atau suatu kekuatan lain dari luar. Frankl berpendapat bahwa kebebasan manusia merupakan kebebasan yang berada dalam batas-batas tertentu. Manusia tidak bebas dari kondisi biologis, psikologis, sosiologis, yang benar-benar dapat mengubah keadaan manusia, namun manusia bebas memilih reaksi-reaksi dan mengambil sikap dalam menangani kondisi tersebut. Menurut Frankl manusia tidak hanya mampu mengambil sikap terhadap dunia, namun juga sanggup dan bebas mengambil sikap terhadap dirinya sendiri. Ketika manusia mengambil sikap atau mengambil jarak terhadap dirinya, manusia dapat keluar dari ruang biologis dan psikologisnya dan kemudian masuk kedalam ruang noologis atau ruang spiritual. Dimensi spiritual inilah yang menyebabkan manusia hadir sebagai suatu fenomena yang berbeda dengan makhluk ciptaan Tuhan lainnya. Dalam ruang noologis ini terletak kebebasan berkeinginan, yang merupakan ciri unik dari keberadaan pengalaman manusia. Frankl juga menekankan bahwa kebebasan manusia bukanlah "kebebasan dari" (freedom from) tetapi "kebebasan untuk" (freedom to), yaitu kebebasan untuk menerima tanggung jawab dalam keadaan sadar. Dengan demikian kebebasan yang dimaksud Frankl bukanlah eskapisme atau lari dari persoalan yang sebenarnya harus dihadapi.
Kebebasan akan makna (will of meaning). Frankl berpendapat bahwa manusia dalam berperilaku mengarahkan dirinya sendiri pada sesuatu yang ingin dicapainya, yaitu makna. Keinginan akan makna inilah yang menjadi penggerak utama kepribadian manusia (Frankl, 1967). Frankl mengkritik prinsip determinisme dan berkeyakinan bahwa manusia dalam berperilaku terdorong untuk mengurangi ketegangan agar memperoleh keseimbangan, dan mengarahkan dirinya sendiri menuju tujuan tertentu yang layak bagi dirinya, yaitu makna (Koeswara, 1987). Oleh karena itu, Frankl lebih suka menggunakan istilah "keinginan akan makna“. Menurutnya apabila makna dipandang sebagai kebutuhan maka sama saja beranggapan bahwa manusia berperilaku didorong kepada pencapaian makna dengan tujuan mencapai keseimbangan, sehingga yang menjadi tujuan utama bukanlah makna melainkan keseimbangan itu sendiri. Tegangan yang dialami manusia bukan semata-mata tegangan yang ditimbulkan oleh naluri-naluri, melainkan tegangan antara keberadaan dan makna. Tegangan ini mengisyaratkan bahwa manusia tidak akan merasa puas dengan keberadaannya tersebut. Oleh karena itu, keinginan akan makna merupakan suatu keinginan utama yang tidak pernah padam dalam diri manusia.

Makna hidup (meaning of life). Frankl mengemukakan bahwa manusia memiliki kapasitas untuk menentukan kebermaknaan atau keberartian hidup dalam penderitaan seberat apapun, bahkan pada saat menghadapi kematian. Kebermaknaan hidup adalah hal yang istimewa karena bersifat unik bagi setiap orang, dan bahkan berbeda dari satu peristiwa ke peristiwa yang lain. Menurut Frankl makna hidup muncul ketika individu memulai pematangan spiritual, yaitu pada masa pubertas (Koeswara, 1987). Makna hidup tersebut bersifat personal dan unik. Hal ini disebabkan karena individu bebas menentukan caranya sendiri dalam menemukan dan menciptakan makna. Selain itu, manusia bersifat personal, tunggal, dan unik. Berarti penciptaan makna hidup menjadi tanggung jawab individu dan tidak dapat diserahkan atau dipercayakan kepada orang lain. Hal ini disebabkan karena hanya individu itu sendirilah yang mampu merasakan atau mengalami makna hidupnya.

Pencarian makna hidup merupakan tugas yang membingungkan dan menantang, serta menyebabkan adanya peningkatan tegangan 
batin yang merupakan prasyarat bagi kesehatan psikologis individu. Menurut Frankl hal ini disebabkan karena suatu kepribadian yang sehat mengandung tingkat tegangan tertentu, antara apa yang telah dicapai atau diselesaikan dengan apa yang harus dicapai atau diselesaikan. Adanya tegangan ini, individu yang sehat selalu memperjuangkan tujuan yang memberikan makna hidup. Perjuangan yang terus-menerus ini menghasilkan kehidupan yang penuh semangat dan kegembiraan. Tanpa adanya makna dalam kehidupan, manusia tidak mempunyai alasan untuk melanjutkan kehidupannya (Frankl, 1967).

Seperti yang telah dikemukakan diatas, makna bersifat unik dan personal. Individu yang satu boleh jadi menciptakan kebermaknaan hidupnya dari keindahan seni atau keindahan alam, sedangkan individu yang lain menciptakan kebermaknaannya dengan kebenaran ang diperjuangkan ataupun cinta yang dijalaninya. Kebermaknaan hidup bersifat personal dan unik karena hidup manusia itu sendiri bersifat personal, tunggal, dan unik. Hal ini menunjukkan bahwa penciptaan makna hidup menjadi tanggung jawab masing-masing manusia sebagai individu, dan dia tidak dapat menyerahkan atau mempercayakan penciptaan makna hidup pribadinya kepada orang lain. Hanya individu bersangkutan sajalah yang bisa merasakan atau mengalami apakah kehidupan ini bermakna atau tidak, serta menghayati apa kebermaknaan hidup itu baginya (Frankl, 1967).

Pendapat penulis berdasarkan uraian yang telah dipaparkan sebelumnya dapat disimpulkan bahwa kebermaknaan hidup adalah kualitas penghayatan individu terhadap seberapa besar dirinya dapat mengembangkan dan mengaktualisasikan potensi-potensi serta kapasitas yang dimilikinya, dan seberapa jauh dirinya telah berhasil mencapai tujuan-tujuan hidupnya, dalam rangka memberi makna atau arti terhadap kehidupannya.

Menurut Frankl manusia secara hakiki mampu menemukan kebermaknaan hidup melalui transendensi diri (Koeswara, 1987). Pendapat tersebut sejalan dengan pendapat Plautzian (1981) yang mengemukakan bahwa perasaan kegamaan yang matang akan membantu individu memuaskan "keinginan akan makna", dengan mengambil ajaran-ajaran agama yang diterapkan pada sebuah kehidupan. Namun demikian, Frankl berpendapat bahwa makna hi- dup tidak selalu merupakan persoalan agama, melainkan bisa dan seringkali merupakan filsafat hidup yang sekuler (Koeswara, 1987).

Manusia dapat menemukan makna melalui realisasi nilai-nilai manusiawi yang meliputi: Nilai-nilai daya cipta. Menurut Frankl nilai-nilai daya cipta adalah apa yang diberikan individu pada kehidupan. Nilai-nilai ini diwujudkan dalam aktivitas yang krteatif dan produktif. Biasanya berkenaan dengan suatu macam pekerjaan. Namun demikian nilai-nilai ini dapat diungkap dalam semua bidang kehidupan. Makna diberikan kepada kehidupan melalui tindakan yang menciptakan suatu hasil yang kelihatan atau suatu ide yang tidak kelihatan, atau dengan melayani orang lain (Schultz, 1991). Nilai-nilai pengalaman. Menurut Frankl nilai-nilai pengalaman adalah apa yang diterima oleh individu dari kehidupan, misalnya menemukan kebenaran, keindahan, dan cinta. Nilai-nilai pengalaman dapat memberikan makna sebanyak nilai-nilai daya cipta. Ada kemungkinan bagi individu untuk memenuhi arti kehidupan dengan mengalami berbagai segi kehidupan secara intensif meskipun individu tersebut tidak melakukan tindakantindakan yang produktif (Schultz, 1991). Nilainilai sikap. Menurut Frankl nilai-nilai sikap adalah sikap yang diberikan individu terhadap kodrat-kodrat yang tidak dapat diubah, seperti penyakit, penderitaan atau kematian. Situasisituasi buruk yang dapat menimbulkan keputusasaan dan tanpa harapan dapat memberikan kesempatan yang sangat besar bagi individu untuk menemukan makna hidupnya (Schultz, 1991). Selain itu makna pribadi dapat bersumber pada keyakinan bahwa manusia seharusnya berjuang untuk mengaktualisasikan dirinya, bahwa manusia seharusnya membaktikan dirinya untuk merealisasikan potensi-potensi yang dimilikinya (Yalom, 1980).

Hasil penelitian Croumbaugh dan Maholick menunjukkan bahwa kebermaknaan hidup berkorelasi dengan tingkat pendidikan, tingkat kecerdasan dan tingkat sosial ekonomi individu (Koeswara, 1987). Semakin tinggi tingkat pendidikan, kecerdasan, dan sosial ekonomi seseorang, maka semakin tinggi pula kebermaknaan hidup orang tersebut.

Yalom (1980) menyebutkan adanya penemuan-penemuan kontradiktif mengenai hubungan antara kebermaknaan hidup dengan jenis kelamin. Kendati demikian secara umum pria menunjukkan tingkat kebermaknaan hidup 
yang lebih tinggi dibandingkan dengan wanita. Hasil penelitian ini dapat dijelaskan atas dasar asumsi bahwa dalam masyarakat patriarkis, pria mendapatkan keuntungan-kebebasan mengalami banyak pengalaman untuk mengembangkan diri, serta memiliki keleluasaan untuk menentukan pilihan maupun mengungkapkan diri (Bhasin dan Khan, 1995). Kondisi semacam ini tentunya akan menyediakan peluang bagi kaum pria untuk menemukan dan menciptakan makna hidup yang lebih beragam dibandingkan kaum wanita. Berbagai penelitian juga menunjukkan bahwa makna hidup yang positif tergantung pada kesesuaian antara tujuan-tujuan dan nilai-nilai individu dengan peran dan kebutuhan struktur yang mengikat individu (Yalom, 1980).

Salah satu identitas yang paling mendasar dari sekian banyak atribut manusia adalah seks. Seksualitas disamping bersifat relasional juga merupakan suatu kategori sosial yang mampu memberi seseorang peran dan status tertentu dalam masyarakat. Demikian juga dengan orientasi seks seseorang. Seorang pria yang telah memilih jalan hidupnya untuk menjadi seorang pria homoseksual akan mengalami tekanan yang begitu besar dari masyarakat di sekitarnya. Masyarakat mempunyai norma yang ditetapkan untuk menilai seseorang atau sekelompok orang yang terlihat dari sifat, pemikiran, perkataan, dan perbuatannya di kehidupan sehari-hari. Pria homoseksual sebagai suatu sifat yang dianggap menyimpang dari norma dan nilai yang berlaku di suatu masyarakat, tentunya menimbulkan berbagai tanggapan negatif dari masyarakat.

Pengalaman hidup pria homoseksual ketika berada di tengah-tengah masyarakat akan membentuk kebermaknaan hidupnya. Pengalaman baik ataupun pengalaman buruk, pengalaman yang paling membahagiakan maupun pengalaman yang paling menyakitkan sama sekali akan ikut berperan dalam pembentukan kebermaknaan hidup seseorang. Hal ini seperti yang pernah dikemukakan oleh Frankl bahwa manusia memilki kapasitas untuk menentukan kebermaknaan atau keberartian hidup dalam penderitaan seberat apapun, bahkan pada saat menghadapai kematian (Koeswara, 1987).

Frankl adalah tokoh pertama yang menggunakan istilah "logoterapi" sekitar tahun 1920-an. Berbeda dengan tokoh psikologi eksistensial lain di Eropa yang pesimistik dan anti agama, Frankl memiliki pandangan yang optimistik terhadap keberadaan manusia dan menempatkan agama sebagai salah satu sistem nilai yang berpengaruh besar terhadap kehidupan manusia (Siahaan dalam Bastaman, 1996).

Psikologi eksistensial membahas segala kemampuan manusia yang tidak mendapatkan pembahasan secara sistematis dalam aliran positivis-behaviourisme ataupun dalam teori klasik psikoanalisa. Misalnya masalah values, proses menjadi (becoming), kreativitas, afeksi, tanggung jawab, dan kebermaknaan (Koeswara, 1987). Salah satu prinsip dasar dari aliran ini adalah keberadaan mengatasi dunia (beingbeyond-the-world). Maksudnya adalah manusia memiliki kemungkinan yang luas untuk mentransendir atau melampaui atau mengatasi "diri" dan lingkungannya, serta merealisasikan potensinya. Konsep mengatasi pada psikologi eksistensial ini dapat menerangkan dan mendeskripsikan secara menarik tentang kemampuan manusia mentransendir "diri" dan lingkungannya, walaupun lingkungan yang dihadapinya tersebut sangat menindas, hororistik, dan penuh penderitaan (Djatmiko dalam Hassan, 1976).

Logoterapi berasal dari dua kata, yaitu logos dan therapy. Logos berarti makna dan therapy berarti prosedur untuk menyembuhkan atau meringankan suatu penyakit. Logoterapi itu sendiri berbicara mengenai arti eksistensi manusia dan kebutuhan manusia akan makna, dan juga teknik-teknik terapeutik khusus untuk menemukan makna dalam kehidupan (Schultz, 1991). kebermaknaan hidup sebagai salah satu dari tiga prinsip utama logoterapi akan dapat lebih dipahami dalam konteks pemahaman logoterapi secara keseluruhan. Tiga konsep utama yang menjadi dasar filosofis logoterapi adalah kebebasan berkeinginan (freedom of will)keinginan akan makna (will of meaning), dan makna hidup (meaning of life) (Koeswara, 1992).

Kebermaknaan hidup adalah kualitas penghayatan individu terhadap seberapa besar dirinya dapat mengembangkan dan mengaktualisasikan potensi-potensi serta kapasitas yang dimilikinya, dan seberapa jauh dirinya telah berhasil mencapai tujuan-tujuan hidupnya, dalam rangka memberi makna atau arti terhadap kehidupannya (Frankl, 1967). Pada penelitian ini tingkat kebermaknaan hidup diukur dengan menggunakan simpulan teori dari James Crumbaugh \& Leonard Maholick (Robinson \& Shover, 1973) yang didasarkan pada konsep 
Frankl, yang berisi aspek-aspek mengenai kebermaknaan hidup. Aspek-aspek tersebut terdiri dari, aspek makna atau arti hidup, kepuasan hidup, kebebasan, sikap terhadap kematian, pemecahan masalah, dan kepantasan hidup.

Jasper mengungkapkan bahwa melalui kebebasan untuk mengukuhkan eksistensinya, manusia terhindar dari suatu eksistensi yang hampa dan tidak bermakna (Hassan, 1976). Menurut Binswanger dan Boss individu yang mampu mewujudkan kemungkinan-kemungkinan dari keberadaannya akan mencapai keberadaan yang sehat yang ditandai oleh keterbukaan terhadap alam, semesta, dan diri sendiri (Koeswara, 1987). Keberadaan sehat ini ditandai pula oleh kemampuan individu untuk menjalani keberadaannya secara terintegrasi yakni mengalami dirinya sebagai pribadi yang utuh dan penuh. Individu tidak merasa dipecah-pecah oleh tuntutan untuk memainkan peran tertentu yang dipaksakan oleh orang lain dan individu juga tidak terperangkap oleh gambaran-gambaran ideal mengenai dirinya serta mampu secara otonom untuk memilih tindakan terbaik bagi dirinya.

Pendapat ini sejalan dengan pendapat Maslow yang mengatakan bahwa manusia akan berkembang menjadi manusia yang utuh apabila berhasil mewujudkan potensinya dengan sebaik-baiknya (Brouwer dkk, 1993). Stagnasi dalam perkembangan yang dikarenakan individu tidak berani mengembangkan dirinya atau dihalangi oleh lingkungan dapat menimbulkan kemunduran, penyakit, bahkan kematian.

Setiap manusia, termasuk kaum pria homoseksual merasakan adanya kemungkinan atau potensi dalam dirinya yang dapat diaktualisasikan. Dengan kebebasan sebagai manusia, kaum pria homoseksual juga dapat memilih, menentukan dan memutuskan potensi-potensi yang akan direalisasikan dan mana yang tidak akan direalisasikan.

Definisi pribadi yang teraktualisasikan secara bebas, Maslow (Goble, 1987) melukiskannya sebagai penggunaan dan pemanfaatan secara penuh bakat, kapasitas-kapasitas, potensi-potensi, dan sebagainya. Menurut Maslow kecenderungan mengaktualisasikan diri dapat dipahami sebagai hasrat individu untuk menjadi seseorang yang sesuai dengan keinginan dan potensi yang dimilikinya. Suatu hasrat untuk menyempurnakan "diri" melalui pengungkapan segenap potensi yang dimiliki- nya (Koeswara, 1987). Adapun aspek-aspeknya terdiri dari aspek pengamatan realitas secara efisien dan menerima diri, berfungsi secara otonom dan resistensi terhadap inkulturasi, minat dan hubungan sosial yang baik, kreatif dan humoris, spontan, wajar, dan demokratis, fokus terhadap masalah diluar dirinya dan dapat membedakan sarana dan tujuan, serta menjalani pengalaman puncak dan apresiasi yang mendalam dan segar.

Maslow berpendapat bahwa aktualisasi diri tidak hanya berupa penciptaan kreasi atau karya berdasarkan bakat dan kemampuan khusus, tetapi dapat dicapai dengan jalan membuat yang terbaik, bekerja dengan sebaik-baiknya sesuai dengan bidangnya.

Seorang pria homoseksual yang mempunyai keinginan untuk mengaktualisasikan segala kemampuan dan potensi yang dimilikinya, akan lebih menemukan makna dalam kehidupannya. Seperti yang diungkapkan oleh Schultz (1991), manusia dapat menemukan makna melalui realisasi dari nilai daya cipta, pengalaman, dan nilai sikapnya. Keinginan untuk mengaktualisasikan potensi-potensinya dalam aktifitas yang kreatif dan produktif, akan membuat seorang pria homoseksual lebih merealisasikan nilai-nilai daya cipta yang ada pada dirinya. Dengan begitu dapat memberikan kesempatan yang sangat besar bagi pria homoseksual untuk menemukan makna hidupnya.

Perjuangan untuk mengaktualisasikan dirinya dan merealisasikan segenap potensi yang dimilikinya akan membawa individu pada kehidupan yang lebih bermakna (Yalom, 1980). Maslow mengemukakan bahwa melalui penemuan dan perwujudan diri, manusia akan mampu mengatasi perasaan bahwa dirinya tidak penting dan tidak bermakna (Cropps, 1993). Individu terlebih dahulu harus mengembangkan pemahaman, bahwa dirinya pantas dan memiliki identitas untuk memperoleh perasaan hidup yang bermakna. Bastaman (1996) lebih lanjut menjelaskan bahwa penemuan makna hidup berkaitan dengan kualitas insani yang meliputi tiga kemampuan eksistensial yaitu transendensi diri, pengenalan dan pengembangan diri, serta humor dan tertawa. Berdasarkan pendapat tersebut maka diduga terdapat hubungan antara kebermaknaan hidup dengan aktualisasi diri seseorang. Makna hidup ditemukan melalui : a) kerja, penemuan keindahan dan kebenaran, serta berbagai pe- 
ngalaman, dan b) kualitas insani yang mencakup transendensi diri, pengenalan dan pengembangan diri, serta humor.

Pria homoseksual dapat berkembang menjadi manusia yang utuh apabila berhasil mewujudkan potensi yang dimilikinya dengan sebaik-baiknya. Dengan kebebasan sebagai manusia, kaum pria homoseksual juga dapat memilih, menentukan, dan memutuskan potensi-potensi mana yang akan direlisasikannya. Untuk itu, kaum pria homoseksual juga harus menjalani keberadaannya secara terintegrasi, yaitu mengalami dirinya sebagai pribadi yang utuh dan penuh, tidak merasa dipecah-pecah oleh tuntutan untuk memainkan peran tertentu yang dipaksakan oleh orang lain atau lingkungannya, dan tidak terperangkap oleh gambaran-gambaran ideal mengenai dirinya, serta mampu secara otonom untuk memilih tindakan-tindakan yang terbaik bagi dirinya. Perjuangan untuk mengaktualisasikan diri kaum pria homoseksual dan merealisasikan segenap potensi yang dimilikinya akan membawa mereka pada kehidupan yang lebih bermakna, sedangkan stagnasi dalam perkembangan yang dikarenakan individu tidak berani mengembangkan dirinya atau dihalangi oleh lingkungan dapat menimbulkan kemunduran dalam kehidupannya. Jadi dapat disimpulkan bahwa kebermaknaan hidup seorang pria homoseksual akan tercapai apabila sudah ada keinginan untuk mengaktualisasikan semua potensi yang dimilikinya.

Berdasarkan uraian yang telah dijelaskan, makapenulis ajukan hipotesis yang merupakan jawaban sementara dari pengujian masalah. Hipotesis dari penelitian ini adalah: Terdapat hubungan positif antara tingkat aktualisasi diri dengan kebermaknaan hidup pada pria homoseksual.

\section{METODE PENELITIAN}

Metode yang akan digunakan dalam penelitian ini adalah rancangan non eksperimental dengan metode korelasional. Populasi dalam penelitian ini adalah pria homoseksual yang menjadi anggota himpunan $\mathrm{X}$ yang memenuhi karakteristik yang telah dipaparkan sebelumnya sejumlah 30 orang. Karena jumlah populasi yang relatif sedikit dan memungkinkan semua anggota populasi digunakan sebagai subjek penelitian, maka penelitian ini akan berbentuk penelitian populatif. Untuk mendapatkan data yang diperlukan dalam penelitian ini, peneliti menggunakan dua macam skala yaitu: (1) Skala aktualisasi diri yang mengacu pada konsep teori yang dikemukakan oleh Maslow (1984). (2) Skala kebermaknaan hidup disusun berdasarkan simpulan teori yang dikemukakan oleh James Crumbaugh dan Leonard Maholick ( Frankl, 1984). Uji statistik yang akan digunakan untuk menguji hipotesis yang diajukan adalah adalah dengan menggunakan formula korelasi dari Rank Spearman (Siegel. 1992), dengan alasan bahwa data dalam penelitian ini berpasangan, data berskala ordinal dan teknik statistik berbentuk nonparametrik.

\section{HASIL DAN PEMBAHASAN}

\section{Hasil}

Berdasarkan hasil perhitungan diketahui bahwa koefisien korelasi antara aktualisasi diri dengan kebermaknaan hidup adalah sebesar 0,685 dengan $P_{\mathrm{v}}$ sebesar 0,000 pada taraf signifikansi $\alpha=0,05$ dengan arah pengujian dua sisi. Berdasarkan kriteria koefisien korelasi Guillford, indeks korelasi sebesar 0,685 tersebut memiliki arti tingkat korelasi tinggi.

Hasil pengujian tersebut, memiliki arti bahwa subjek yang memiliki tingkat aktualisasi diri tinggi, umumnya juga memiliki tingkat kebermaknaan hidup yang tinggi. Sebaliknya, subjek yang memiliki tingkat aktualisasi diri yang rendah, umumnya juga memiliki tingkat kebermaknaan hidup yang rendah.

\section{Pembahasan}

Hasil pengujian hipotesis menunjukkan bahwa aktualisasi diri secara signifikan berhubungan dengan kebermaknaan hidup. Berdasarkan hasil analisis, diperoleh hasil koefisien korelasi sebesar 0,685. Berdasarkan hasil perhitungan tersebut maka hipotesis yang diajukan dalam penelitian ini dapat diterima yaitu terdapat hubungan yang positif antara aktualisasi diri dengan kebermaknaan hidup. Hal tersebut memiliki arti bahwa tingkat aktualisasi diri secara signifikan berhubungan dengan tingkat kebermaknaan hidup. Dengan kata lain, seorang pria homoseksual yang mempunyai keinginan untuk mengaktualisasikan segala kemampuan dan potensi yang dimilikinya, akan lebih menemukan makna dalam kehidupannya. 
Seperti yang diungkapkan oleh Schultz (1991), manusia dapat menemukan makna melalui realisasi dari nilai daya cipta, pengalaman, dan nilai sikapnya. Keinginan untuk mengaktualisasikan potensi-potensinya dalam aktifitas yang kreatif dan produktif, akan membuat seorang pria homoseksual lebih merealisasikan nilai-nilai daya cipta yang ada pada dirinya. Dengan begitu dapat memberikan kesempatan yang sangat besar bagi pria homoseksual untuk menemukan makna hidupnya.

Tingkat aktualisasi diri yang dimiliki pria homoseksual berhubungan dengan tingkat kebermaknaan hidupnya. Karena ketika pria homoseksual merasakan adanya kemungkinan atau potensi dalam dirinya yang dapat diaktualisasikan, maka ia dapat memilih, menentukan dan memutuskan potensi-potensi yang akan direalisasikan dan mana yang tidak akan direalisasikan. Perjuangan untuk mengaktualisasikan dirinya dan merealisasikan segenap potensi yang dimilikinya tersebut akan membawa individu pada kehidupan yang lebih bermakna (Yalom, 1980).

Maslow mengemukakan bahwa melalui penemuan dan perwujudan diri, manusia akan mampu mengatasi perasaan bahwa dirinya tidak penting dan tidak bermakna (Cropps, 1993). Untuk mewujudkan hal tersebut, maka seorang pria homoseksual terlebih dahulu harus mengembangkan pemahaman, bahwa dirinya pantas dan memiliki identitas untuk memperoleh perasaan hidup yang bermakna.

Pria homoseksual yang mampu mengaktualisasikan dirinya akan mampu menemukan kebermaknaan dalam hidupnya. Begitu pula sebaliknya, ketika ia sudah menemukan kebermaknaan dalam hidup, maka ia pun dapat mengaktualisasikan dirinya dengan baik. Seperti yang dikemukakan oleh (Maxmen, 1986) bahwa homoseksual yang mampu menerima keadaan dirinya pada umumnya dapat mengembangkan dirinya dengan baik.

Dalam masyarakat kelompok homoseksual ini umumnya mempunyai prestasi yang cukup bagus dan karyanya dapat diterima oleh masyarakat. Hasil penelitian beberapa ahli psikologi menunjukkan, orang-orang homoseksual yang mampu menerima diri mampu mencapai status pendidikan, pekerjaan, dan ekonomi sama tingginya dengan orang-orang yang bukan homoseksual, bahkan kadang-kadang lebih tinggi. Suatu penelitian pada wanita lesbian, menunjukkan bahwa seorang lesbian dapat le- bih mandiri, fleksibel, dominan dan dapat mencukupi kebutuhannya sendiri. Kelompok homoseksual yang mampu menerima keberadaan dirinya tidak mengalami kecemasan dan kesulitan psikologis lebih banyak daripada para heteroseks. Pasalnya, mereka menerima dan tidak terganggu secara psikis dengan orientasi seksual mereka, sehingga mampu menjalankan fungsi sosial dan seksualnya secara efektif. Tentu saja mereka tidak akan berkonsultasi dengan kalangan profesional karena mereka tidak mempersalahakan keadaan dirinya.

Terdapat hal menarik dari data deskriptif yang dijelaskan sebelumnya, yaitu terdapat sebagian (10\%) subjek yang memiliki tingkat aktualisasi diri yang tinggi namun memiliki kebermaknaan hidup yang rendah. Hal tersebut mungkin saja terjadi, dan salah satu faktor penyebabnya adalah karena adanya penolakan dari lingkungan terhadap dirinya. Menurut Psikolog Erida Rusli Sukardi (Hai, 2001), sikap tidak menerima yang diperlihatkan lingkungan sekitar menyebabkan seorang homoseksual merasa tertekan dan terkucil. Mereka sering diliputi perasaan bersalah dan harus hidup dalam kepura-puraan.

Pengalaman hidup pria homoseksual ketika berada di tengah-tengah masyarakat akan membentuk kebermaknaan hidupnya. Pengalaman baik ataupun pengalaman buruk, pengalaman yang paling membahagiakan maupun pengalaman yang paling menyakitkan sama sekali akan ikut berperan dalam pembentukan kebermaknaan hidup seseorang. Hal ini seperti yang pernah dikemukakan oleh Frankl bahwa manusia memilki kapasitas untuk menentukan kebermaknaan atau keberartian hidup dalam penderitaan seberat apapun, bahkan pada saat menghadapai kematian (Koeswara, 1987).

Hal menarik lainnya adalah terdapat sebagian (10\%) subjek lainnya yang memiliki tingkat aktualisasi diri yang rendah namun memiliki tingkat kebermaknaan hidup yang tinggi. Hal tersebut mungkin saja terjadi, apabila pria homoseksual tersebut mampu menerima keadaan dirinya apa adanya serta mendapatkan dukungan dari lingkungan.

Jasper mengungkapkan bahwa melalui kebebasan untuk mengukuhkan eksistensinya, manusia terhindar dari suatu eksistensi yang hampa dan tidak bermakna (Hassan, 1976). Menurut Binswanger dan Boss individu yang mampu mewujudkan kemungkinan-kemungkinan dari keberadaannya akan mencapai ke- 
beradaan yang sehat yang ditandai oleh keterbukaan terhadap alam, semesta, dan diri sendiri (Koeswara, 1987). Keberadaan sehat ini ditandai pula oleh kemampuan individu untuk menjalani keberadaannya secara terintegrasi yakni mengalami dirinya sebagai pribadi yang utuh dan penuh. Individu tidak merasa dipecah-pecah oleh tuntutan untuk memainkan peran tertentu yang dipaksakan oleh orang lain dan individu juga tidak terperangkap oleh gam-baran-gambaran ideal mengenai dirinya serta mampu secara otonom untuk memilih tindakan terbaik bagi dirinya.

Pendapat ini sejalan dengan pendapat Maslow yang mengatakan bahwa manusia akan berkembang menjadi manusia yang utuh apabila berhasil mewujudkan potensinya dengan sebaik-baiknya (Brouwer dkk, 1993). Stagnasi dalam perkembangan yang dikarenakan individu tidak berani mengembangkan dirinya atau dihalangi oleh lingkungan dapat menimbulkan kemunduran, penyakit, bahkan kematian.

\section{SIMPULAN DAN SARAN}

\section{Simpulan}

Berdasarkan hasil analisis dan pembahasan tentang hubungan antara tingkat aktualisasi diri dengan kebermaknaan hidup pada pria homoseksual di Himpunan X di kota Bandung dapat ditarik simpulanbahwa terdapat hubungan positif yang signifikan, antara tingkat aktualisasi diri dengan kebermaknaan hidup pada pria homoseksual di Himpunan X di kota Bandung.

\section{Saran}

Berdasarkan hasil penelitian yang telah dilakukan, dengan memperhatikan keterbatasan-keterbatasan dalam penelitian ini, peneliti mengajukan saran-saran agar dapat dijadikan bahan pertimbangan sebagai berikut:

Bagi lembaga, dikarenakan hasil penelitian menunjukkan bahwa tingkat aktualisasi diri berhubungan dengan kebermaknaan hidup, maka peneliti memberikan saran bagi lembaga untuk memberikan pelatihan-pelatihan kepada para anggotanya sesuai dengan minat atau profesi yang digelutinya, sehingga setiap anggota dapat mengembangkan kemampuannya sesuai dengan minat yang dimilikinya.
Saran lain bagi lembaga, karena dukungan sosial diduga menjadi salah satu faktor penunjang tingginya tingkat kebermaknaan hidup, maka disarankan kepada lembaga untuk mengadakan kegiatan diskusi sebagai media untuk berbagi pengalaman serta menginspirasi setiap anggota kelompok sehingga merasa hidupnya lebih bermakna.

Untuk penelitian selanjutnya, karena pada penelitian ini masih terdapat kasus yang cukup menarik dan perlu dijawab serta diteliti kembali yaitu terdapat subjek yang memiliki tingkat aktualisasi diri yang tinggi namun memiliki tingkat kebermaknaan hidup yang rendah, begitu pula sebaliknya terdapat subjek yang memiliki tingkat aktualisasi diri yang rendah namun memiliki tingkat kebermaknaan hidup yang tinggi. Karenanya, peneliti memberi masukkan kepada peneliti lain untuk mencari variabel lain yang diduga memiliki hubungan yang lebih signifikan dengan kebermaknaan hidup.

\section{DAFTAR PUSTAKA}

Adian, Husain. 2005. Homoseksual dan Umat Islam. http://dudung.net/index.php/=dep an $\&$ action $=$ detail $\&$ id $=631 \&$ cat $=4$

Adlany, Nazry. 1993. Al Quran Terjemah Indonesia. Jakarta, Sari Agung.

Allyn \& Bacon. 1993. Human Sexuality

Amiruddin \& Sulistyo. 2004. Sex Tak Sekadar Birahi. Bandung : Granada.

Anonim. 2005. Perbedaan homoseksual, Biseksual, Transgender \& Pelacur Pria. http://blog.360.yahoo.com/blog-asrre T4hcLPoV6BPW.jEug--?p=342.

Anonim. 2010. Penolakan Keras Kongres Gay se-Asia. Liputan6.com

Arikunto, S. 2000. Manajemen Penelitian. Jakarta: Rineka cipta.

Azwar, S. 2004. Metode penelitian. Yogyakarta : Pustaka Pelajar.

2000. Reliabilitas dan Validitas. Yogyakarta : Pustaka pelajar.

Bastaman, 1996. Meraih Hidup Bermakna; Kisah Pribadi dengan Pengalaman Tragis. Jakarta : Paramadina.

Brouwer, P. M. A. W. 1975. Psychoterapi. Pandangan Beberapa Methoda Dan Tek-nik. Bandung: Fakultas Psikologi UNPAD. 
Coleman, J. C. And Broen, W. E. Jr. 1974. Abnormal Psychology And Modern Life. India : D.B Taraporevala Sons and Co.

Corsini, R. 1972. Current psychoterapies. Illinois : F.E Peacock Publisher, Inc.

Crooks, Robert. 1983. Our sexuality. California, Benjamin Cumming.

Cropps, R. W. 1993. Dialog Psikologi dan Agama. (Terjemahan). Yogyakarta: Kanisius.

Eysenck. 1977. Handbook of Abnormal Psychology.

Frankl, V. E. 1967. Man's Search For Meaning : An Introduction To Logotherapy. London : Hoddar and Stooghton.

1984. Psychoterapy and Existentialism. New York: Washington Sguare Press.

Fryda. 2001. Kebermaknaan Hidup Kaum Gay. Skripsi (tidak diterbitkan). Yogyakarta : Fakultas Psikologi UGM.

Goble, F. G. 1987. Mazhab Ketiga Psikologi Humanistik Abraham Maslow. (Alih Bahasa Supratiknya). Yogyakarta: Kanisius.

Hassan, F. 1976. Berkenalan Dengan Eksistensialisme. Jakarta : P.T. Dunia Pustaka Jaya.

Hidayat, Teddy. 2005. Homoseksual. Bandung. Pikiran Rakyat Online

Kartono, Kartini. 1989. Psikologi Abnormal dan Normalitas Seksual, Bandung, Mandar Maju.

Kinsey, A. C., Pomeroy, W. B., \& Martin, C. E. 1949. Sexual Behavior In The Human Male. London: W. B. Saunders Company.

Kelly. 2001. Sexuality Today. New York,. Mc. Gran Hill.

Koeswara, E. 1987. Psikologi Eksistensial Suatu Pengantar. Bandung : P.T Eresco 1992. Logoterapi, Psikoterapi Viktor Frankl. Yogyakarta : Kanisius

Lumenta, L. 1996. Stress Dan Tendensi Depresi pada Kelompok Homoseksual dan
Heteroseksual. Skripsi (tidak diterbitkan). Yogyakarta: Fakultas Psikologi UGM.

Maslow, A. H. 1984. Self actualization. New York : Harper \& Row.

Maxmen, J. S. 1986. Essential Psychopathology. New York : W. W. Norton \& Company.

Ninuk. 2006.Ini Persoalan Definisi Seksual http://www.kompas.com/kesehatan/new s/0601/22/083913.htm.

Oetomo, D. 2001. Memberi Suara Pada Yang Bisu. Yogyakarta : Galang Press.

Plautzian, R. F. 1981. Purpose In Life and Value Change Following Conversion. Journal of Personality and Social Psychology.

Robinson, J. P. \& Shover, P. E. 1973. Measures Of Social Psychological Attitudes. Michigan: SurveybResearch Centre, Insitute For Social Research, The university Of Michigan.

Rogers, C. R. 1961. On Becoming A Person. Boston : Houghton Mifflin Company.

Schultz, D. 1991. Psikologi Pertumbuhan : Model-model Kepribadian Sehat. Yogyakarta : Kanisius.

Stevenson, J. E. (ed.) 1985. Recent Research In developmental Psychopathology. A Book Supplement To The journal Of Child Psychology and Psychiatry, Number 4. New york: Pergamon Press.

Sukardi, E. R. 2001. Homoseksualitas. Majalah Hai. Edisi Januari, Th XXXI

Supardi, Sawitri. 2005. Bunga Rampai Kasus Gangguan Psikoseksual. Bandung, Alfabeta.

Wirawan, Sarlito. 1990. Psikologi Sosial. Jakarta : Rineka Cipta

Yalom, I. D. 1980. Laki-laki Yang Secara Emosional Dan Seksual Tertarik kepada Laki-Laki. New York : Basic Books. Inc. Publishers.

Yusuf, Y. 1984. Homologi : Dilema Gay Beragama. Gaya Nusantara. No. 43, 2003. 